\title{
Colocolic intussusception in children: A case series and literature review
}

\author{
Jiayu Yan \\ Beijing Children's Hospital \\ Qiulong Shen \\ Beijing Children's Hospital \\ Chunhui Peng \\ Beijing Children's Hospital \\ Wenbo Pang \\ Beijing Children's Hospital \\ Yajun Chen ( $\square$ chenyajunmd@126.com) \\ Capital Medical University
}

\author{
Research Article \\ Keywords: Colocolic intussusception, Children, Pathologic lead point, Treatment \\ Posted Date: January 13th, 2022 \\ DOI: https://doi.org/10.21203/rs.3.rs-1197972/v1 \\ License: @ (i) This work is licensed under a Creative Commons Attribution 4.0 International License. Read Full License
}

Version of Record: A version of this preprint was published at Frontiers in Surgery on April 6th, 2022. See the published version at https://doi.org/10.3389/fsurg.2022.873624. 


\section{Abstract \\ Background}

Colocolic intussusceptions is a rare subtype of intussusception mostly caused by juvenile polyps. The treatment of colocolic intussusception caused by other pathologic lead points remains poorly understood.

\section{Methods}

A systematic literature review between January 2000 and June 2021 was performed to characterize the comprehensive treatment of colocolic intussusception in children. This report also included 10 patients admitted to our center between 2010 and 2020 not previously reported in the literature.

\section{Results}

We identified 27 patients in 20 studies in addition to 10 patients from our center for a total of 37 patients (median age, 4.0 years; $54.1 \%$ male). The lead point was identified in 33 patients $(33 / 37,89.2 \%)$. The most common lead point was juvenile polyps (16/33, 48.5\%). A therapeutic enema was performed in 12 patients with colocolic intussusception caused by juvenile polyps and was successful in 8 patients $(8 / 12,66.7 \%)$. Colonoscopic polypectomy was subsequently performed in 7 patients and was successful in 6 patients $(6 / 7,85.7 \%)$. The other patient had undergone laparoscopic exploration, and no abnormality was found. Subsequently, the patient underwent open surgery. The patients with colocolic intussusception caused by other pathologic lead points almost underwent surgical treatment $(14 / 17,82.4 \%)$, including 12 open surgeries and 2 laparoscopic surgeries.

\section{Conclusion}

A therapeutic enema followed by colonoscopic polypectomy is feasible to treat colocolic intussusception caused by juvenile polyps unless the patient has bowel perforation; however, open surgery is sometimes needed. For patients with colocolic intussusception caused by other pathologic lead points, open surgery may be preferable to laparoscopic surgery.

\section{Background}

Intussusception is one of the most common abdominal emergencies in children. It often occurs near the ileocecal junction and rarely only involves the colon [1, 2]. Approximately $90 \%$ of ileocolic intussusception cases are idiopathic, and most can be resolved by nonoperative reduction with therapeutic enema [2,3]. However, almost all colocolic intussusceptions are caused by pathologic lead points and should be treated with surgical interventions, including colonoscopic polypectomy, open surgery or laparoscopic surgery [4-8]. The most common lead point in colocolic intussusception is juvenile polyps [6].

The available literature on colocolic intussusception is sparse, at best, and consists mainly of case reports. Some case reports have shown that a successful therapeutic enema followed by colonoscopic polypectomy is feasible to treat colocolic intussusception caused by a juvenile polyp, but open surgery is still used in most cases [6, 7, 9]. Additionally, the effect of laparoscopic surgery on colocolic intussusception is controversial and that the treatment of colocolic intussusception caused by other lead points remians still poorly understood. Thus, we performed this retrospective study to summarize the clinical features of colocolic intussusception using the largest sample size in China and a review of the literature to provide evidence that could be used to improve treatment in clinical practice [10].

\section{Methods}

\section{Study population}

After approval by the Ethics Committee of Beijing Children's Hospital (approval number [2021]-E-090-R), the medical records of all children diagnosed with intussusception and admitted to Beijing Children's Hospital between January 2010 and December 2020 were 
retrospectively reviewed. Patients diagnosed with colocolic intussusception and confirmed by colonoscopy or open surgery were included. The collected data included demographics, clinical symptoms, accompanying malformations, imaging data, clinical interventions, and pathological data.

\section{Search strategy}

The study was performed in accordance with the PRISMA guidelines. The following databases were searched through June 30, 2021: PubMed, Web of Science and the Cochrane Library. Search strings included colocolic intussusception, pediatric, child and children (Table 1). The reference lists of the relevant studies were manually-searched to identify other potentially appropriate studies.

Retrospective studies, including case reports and case series that assessed the treatment of colocolic intussusception, were included. Studies investigating adults, reviews, studies not written in English, studies lacking complete data, and studies without the outcomes of interest were excluded. Additionally, to explore the progress of the treatment of colon intussusception and provide evidence that would be useful in clinical practice, studies published before 2000 were also excluded.

Table 1

Database search results

\begin{tabular}{|c|c|c|c|}
\hline Search term & Colonic intussusception, Pediatric & Colonic intussusception, Child & Colonic intussusception, Children \\
\hline PubMed ${ }^{a}$ & 11 & 25 & 6 \\
\hline Web of Science ${ }^{b}$ & 9 & 19 & 19 \\
\hline $\begin{array}{l}\text { the Cochrane } \\
\text { Libraryc }\end{array}$ & 2 & 3 & 3 \\
\hline \multicolumn{4}{|c|}{$\begin{array}{l}\text { asearch query: (colocolic intussusception [Title/Abstract] AND pediatric [Title/Abstract]), (colocolic intussusception } \\
\text { [Title/Abstract] AND child [Title/Abstract]), (colocolic intussusception [Title/Abstract] AND children [Title/Abstract]) }\end{array}$} \\
\hline \multicolumn{4}{|c|}{$\begin{array}{l}\text { bSearch query: TS = (colocolic intussusception AND pediatric), TS = (colocolic intussusception AND child), TS = (colocolic } \\
\text { intussusception AND children). TS = Top search }\end{array}$} \\
\hline \multicolumn{4}{|c|}{$\begin{array}{l}\text { cSearch query: colonic intussusception in Title Abstract Keyword AND pediatric in Title Abstract Keyword, colonic intussusception } \\
\text { in Title Abstract Keyword AND child in Title Abstract Keyword, colonic intussusception in Title Abstract Keyword AND children in } \\
\text { Title Abstract Keyword }\end{array}$} \\
\hline
\end{tabular}

\section{Results}

\section{Authors' cases}

A total of 1278 patients were diagnosed with intussusception and admitted to Beijing Children's Hospital between January 2010 and December 2020. Among these patients, 10 (0.8\%) were diagnosed with colocolic intussusception; these patients are listed in Table 2. The median age at presentation was $3.3(2.8,5.7)$ years, and 3 patients were male. Six patients had been misdiagnosed at other hospitals. Abdominal ultrasound was performed in all patients, with a positive rate of $100.0 \%$. Juvenile polyps were identified as the lead point in 8 patients, and 6 had polyps situated in the left colon. Therapeutic air enema was performed in 6 patients diagnosed with colonic polyps by ultrasound that successfully reduced intussusception in 5 patients. Among the patients in whom therapeutic air enema was successful, 4 with pedunculated polyps underwent colonoscopic polypectomy, and the other patient, who had a sessile polyp, underwent segmental colonic resection. The patient in whom the therapeutic enema was unsuccessful was treated with segmental colonic resection. Colon duplication was identified as the lead point on ultrasound in 2 patients, and surgical reduction with segmental colonic resection was subsequently performed. 
Table 2

Clinical features of 10 patients with colocolic intussusception at our center between 2010 and 2020

\begin{tabular}{|c|c|c|c|c|c|c|c|c|}
\hline Case & Gender & $\begin{array}{l}\text { Age } \\
\text { (years) }\end{array}$ & Symptoms & Misdiagnosis & Ultrasound & Air enema & Treatment & $\begin{array}{l}\text { Location/lead } \\
\text { point }\end{array}$ \\
\hline 1 & Female & 6.9 & $\begin{array}{l}\text { Abdominal } \\
\text { pain, } \\
\text { palpable } \\
\text { mass, } \\
\text { bloody } \\
\text { stool }\end{array}$ & Enterospasm & $\begin{array}{l}\text { Colocolic } \\
\text { intussusception } \\
(+) \\
\text { Polyp (+) }\end{array}$ & $\begin{array}{l}\text { Yes, } \\
\text { successful }\end{array}$ & $\begin{array}{l}\text { Colonoscopic } \\
\text { polypectomy }\end{array}$ & $\begin{array}{l}\text { Descending } \\
\text { colon } \\
\text { Juvenile } \\
\text { polyp }\end{array}$ \\
\hline 2 & Female & 5.3 & $\begin{array}{l}\text { Abdominal } \\
\text { pain, } \\
\text { palpable } \\
\text { mass }\end{array}$ & No & $\begin{array}{l}\text { Colocolic } \\
\text { intussusception } \\
(+) \\
\text { Polyp (+) }\end{array}$ & $\begin{array}{l}\text { Yes, } \\
\text { successful }\end{array}$ & $\begin{array}{l}\text { Colonoscopic } \\
\text { polypectomy }\end{array}$ & $\begin{array}{l}\text { Descending } \\
\text { colon } \\
\text { Juvenile } \\
\text { polyp }\end{array}$ \\
\hline 3 & Male & 2.6 & $\begin{array}{l}\text { Abdominal } \\
\text { pain, } \\
\text { palpable } \\
\text { mass, } \\
\text { bloody } \\
\text { stool }\end{array}$ & Gastroenteritis & $\begin{array}{l}\text { Colocolic } \\
\text { intussusception } \\
(+) \\
\text { Polyp (+) }\end{array}$ & $\begin{array}{l}\text { Yes, } \\
\text { successful }\end{array}$ & $\begin{array}{l}\text { Colonoscopic } \\
\text { polypectomy }\end{array}$ & $\begin{array}{l}\text { Descending } \\
\text { colon } \\
\text { Juvenile } \\
\text { polyp }\end{array}$ \\
\hline 4 & Male & 3.3 & $\begin{array}{l}\text { Abdominal } \\
\text { pain, } \\
\text { bloody } \\
\text { stool }\end{array}$ & Gastroenteritis & $\begin{array}{l}\text { Colocolic } \\
\text { intussusception } \\
(+) \\
\text { Polyp (+) }\end{array}$ & $\begin{array}{l}\text { Yes, } \\
\text { successful }\end{array}$ & $\begin{array}{l}\text { Colonoscopic } \\
\text { polypectomy }\end{array}$ & $\begin{array}{l}\text { Splenic } \\
\text { flexure } \\
\text { Juvenile } \\
\text { polyp }\end{array}$ \\
\hline $5^{a}$ & Male & 2.8 & $\begin{array}{l}\text { Abdominal } \\
\text { pain, } \\
\text { diarrhea }\end{array}$ & $\begin{array}{l}\text { Mesentery } \\
\text { lymphadenites }\end{array}$ & $\begin{array}{l}\text { Colocolic } \\
\text { intussusception } \\
(+) \\
\text { Polyp (+) }\end{array}$ & No & Open surgery & $\begin{array}{l}\text { Hepatic } \\
\text { flexure } \\
\text { Juvenile } \\
\text { polyp }\end{array}$ \\
\hline 6 & Female & 0.7 & $\begin{array}{l}\text { Abdominal } \\
\text { pain, } \\
\text { palpable } \\
\text { mass, } \\
\text { bloody } \\
\text { stool }\end{array}$ & No & $\begin{array}{l}\text { Colocolic } \\
\text { intussusception } \\
(+) \\
\text { Polyp (+) }\end{array}$ & $\begin{array}{l}\text { Yes, } \\
\text { successful }\end{array}$ & $\begin{array}{l}\text { Colonoscopy, } \\
\text { open surgery }\end{array}$ & $\begin{array}{l}\text { Descending } \\
\text { colon } \\
\text { Juvenile } \\
\text { polyp }\end{array}$ \\
\hline 7 & Female & 3.2 & $\begin{array}{l}\text { Abdominal } \\
\text { pain, } \\
\text { palpable } \\
\text { mass }\end{array}$ & $\begin{array}{l}\text { Mesentery } \\
\text { lymphadenites }\end{array}$ & $\begin{array}{l}\text { Colocolic } \\
\text { intussusception } \\
(+) \\
\text { Polyp (+) }\end{array}$ & $\begin{array}{l}\text { Yes, } \\
\text { unsuccessful }\end{array}$ & Open surgery & $\begin{array}{l}\text { Descending } \\
\text { colon } \\
\text { Juvenile } \\
\text { polyp }\end{array}$ \\
\hline 8 & Female & 4.2 & $\begin{array}{l}\text { Abdominal } \\
\text { pain }\end{array}$ & No & $\begin{array}{l}\text { Colocolic } \\
\text { intussusception } \\
(+) \\
\text { Polyp (+) }\end{array}$ & No & Open surgery & $\begin{array}{l}\text { Hepatic } \\
\text { flexure } \\
\text { Juvenile } \\
\text { polyp }\end{array}$ \\
\hline 9 & Female & 3.2 & $\begin{array}{l}\text { Abdominal } \\
\text { pain, } \\
\text { vomiting }\end{array}$ & $\begin{array}{l}\text { Mesentery } \\
\text { lymphadenites }\end{array}$ & $\begin{array}{l}\text { Colocolic } \\
\text { intussusception } \\
(+) \\
\text { Enteric } \\
\text { duplication }(+)\end{array}$ & No & Open surgery & $\begin{array}{l}\text { Ascending } \\
\text { colonic } \\
\text { duplication }\end{array}$ \\
\hline $10^{\mathrm{b}}$ & Female & 16.5 & $\begin{array}{l}\text { Abdominal } \\
\text { pain, } \\
\text { prolapsed } \\
\text { bowel, } \\
\text { bloody } \\
\text { stool }\end{array}$ & No & $\begin{array}{l}\text { Colocolic } \\
\text { intussusception } \\
(+) \\
\text { Enteric } \\
\text { duplication }(+)\end{array}$ & No & $\begin{array}{l}\text { Open } \\
\text { surgery }^{\text {a }} \\
\text { Colonoscopy }\end{array}$ & $\begin{array}{l}\text { Total colonic } \\
\text { duplication }\end{array}$ \\
\hline
\end{tabular}




\section{Literature search}

The search identified 111 studies, including 97 from databases and 14 from citation searching (Fig. 1). Forty-one studies had undergone full-text review, and 21 were excluded because they were published before 2000, lacked incomplete data, did not report the outcome of interest, and were not about colocolic intussusception or pediatric cases. Twenty studies were included, and 37 patients, including our 10 patients, were evaluated (Table 3) [5-24]. 
Table 3

Studies from 2000 in order of year of publication $(n=20)$

\begin{tabular}{|c|c|c|c|c|c|c|}
\hline Year & Author (s) & $\begin{array}{l}\text { Patients } \\
\text { (n) }\end{array}$ & $\begin{array}{l}\text { Age } \\
\text { (years) }\end{array}$ & Gender & Location & Lead point \\
\hline 2004 & Pritzker et al. & 1 & 11.0 & Female & Left colon & Hereditary angioneurotic edema \\
\hline 2005 & $\begin{array}{l}\text { Abantanga et } \\
\text { al. }\end{array}$ & 1 & 3.0 & Male & Terminal ileum & $\begin{array}{l}\text { Ileal invagination of the sigmoid colon } \\
\text { a }\end{array}$ \\
\hline 2005 & Hafen et al. & 1 & 17.0 & Male & -- & No lead point \\
\hline 2008 & Tennant et al. & 1 & 0.2 & Male & -- & No lead point \\
\hline 2008 & Soccorso et al. & 1 & 5.0 & Female & Sigmoid colon & Ganglioneuroma \\
\hline 2008 & Rahim et al. & 1 & 7.0 & Male & -- & No lead point \\
\hline 2009 & Al-Jahdali et al. & 1 & 0.2 & Female & Unknown & Lymphangioma \\
\hline 2010 & Utsumi et al. & 1 & 2.8 & Male & Cecum & Capillary hemangioma \\
\hline 2012 & Sanchez et al. & 1 & 4.0 & Female & Cecum & $\begin{array}{l}\text { Submucosal edema } \\
\text { with enlarged lymphatics }{ }^{b}\end{array}$ \\
\hline 2012 & Abrahams et al. & 1 & 4.0 & Male & Transverse colon & Juvenile polyp \\
\hline 2013 & Das et al. & 1 & 13.0 & Male & $\begin{array}{l}\text { Descending } \\
\text { colon }\end{array}$ & Mucinous adenocarcinoma \\
\hline 2013 & Simmi et al. & 1 & 0.2 & Female & Sigmoid colon & Gastrointestinal stromal tumor \\
\hline 2014 & Takahashi et al. & 1 & 10.0 & Female & Transverse colon & Juvenile polyp \\
\hline 2014 & Kurian et al. & 1 & 0.3 & Male & Cecum & Kaposiform hemangioendothelioma \\
\hline 2016 & Tripathy et al. & 1 & 7.0 & Male & Transverse colon & Juvenile polyp \\
\hline 2016 & Adorisio et al. & 1 & 8.0 & Male & Unknown & Enterobius vermicularis \\
\hline 2017 & Eid et al. & 1 & 10.0 & Male & Left colon & Synovial sarcoma \\
\hline 2018 & Rehan et al. & 1 & 0.2 & Female & Unknown & Infantile hemangioma \\
\hline 2018 & Brundler et al. & 1 & 1.5 & Male & Transverse colon & Lipoblastoma \\
\hline \multirow[t]{8}{*}{2020} & \multirow[t]{8}{*}{ Richer et al. } & \multirow[t]{8}{*}{8} & 1.8 & Male & -- & No lead point \\
\hline & & & 2.6 & Male & Left colon & Juvenile polyp \\
\hline & & & 3.5 & Female & Left colon & Juvenile polyp \\
\hline & & & 4.0 & Male & Left colon & Juvenile polyp \\
\hline & & & 5.5 & Male & Left colon & Juvenile polyp \\
\hline & & & 14.6 & Male & Left colon & Juvenile polyp \\
\hline & & & 4.6 & Female & Left colon & Hamartomatous polyp \\
\hline & & & 7.8 & Female & Left colon & Leiomyoma \\
\hline
\end{tabular}

Characteristics, diagnosis and treatment 
The median age at presentation was $4.0(2.6,7.4)$ years old. Twenty patients $(20 / 37,54.1 \%)$ were male. The lead point was identified in 33 patients $(33 / 37,89.2 \%)$. The most common lead point was juvenile polyps $(16 / 33,48.5 \%)$, all of which were situated in the distal colon, specifically the left colon, followed by colon duplication $(2 / 33,6.1 \%)$, and other lead points were rare and sporadic.

The diagnosis and treatment of patients are summarized in Table 4. The most common clinical symptoms were abdominal pain, bloody stool, and vomiting, which were identified in $91.9 \%, 67.5 \%$, and $48.6 \%$ of the patients, respectively. Sixteen patients (16/37, $43.2 \%)$ had all three symptoms. Other symptoms comprised palpable mass $(14 / 37,37.8 \%)$, diarrhea $(8 / 37,21.6 \%)$, and rectal mass or prolapse $(6 / 37,16.2 \%)$. Fourteen patients $(14 / 37,37.8 \%)$ had been previously misdiagnosed. Ultrasound was performed in 30 patients (30/37, 81.1\%), $27(27 / 30,90.0 \%)$ with indications of intussusception. Abdominal X-ray was performed in 17 patients (17/37, 45.9\%), 15 (15/17, 88.2\%) with indications of intestinal obstruction. Computed tomography was performed in 9 patients (9/37, 24.3\%), all of whom had indications of intussusception. Barium enema was performed in 5 patients $(5 / 37,13.5 \%)$, all of whom had indications of filling defects in the colon or rectum. 
Table 4

Diagnosis and treatment of patients with colocolic intussusception $(\mathrm{N}=37)$

\begin{tabular}{|c|c|}
\hline Characteristics & Results $^{d}$ \\
\hline Age at presentation, years & $4.0(2.6,7.4)$ \\
\hline Accompanying malformations ${ }^{a}, \mathrm{n}(\%)$ & $4(10.8)$ \\
\hline \multicolumn{2}{|l|}{ Symptoms ${ }^{\mathrm{b}}, \mathrm{n}(\%)$} \\
\hline Abdominal pain & $34(91.9)$ \\
\hline Bloody stool & $25(67.5)$ \\
\hline Vomiting & $18(48.6)$ \\
\hline Palpable mass & $14(37.8)$ \\
\hline Diarrhea & $8(21.6)$ \\
\hline Rectal mass or prolapse & $6(16.2)$ \\
\hline Misdiagnosis ${ }^{\mathrm{c}}, \mathrm{n}(\%)$ & $14(37.8)$ \\
\hline \multicolumn{2}{|l|}{ Diagnostic method, n (\%) } \\
\hline Ultrasound & $30(81.1)$ \\
\hline Abdominal X-ray & $17(45.9)$ \\
\hline Computed tomography & $9(24.3)$ \\
\hline Barium enema & $5(13.5)$ \\
\hline Therapeutic enema (air/saline/ barium), n (\%) & $21(56.8)$ \\
\hline \multicolumn{2}{|l|}{ Treatment for intussusception, n (\%) } \\
\hline Open surgery & $17(45.9)$ \\
\hline Colonoscopy & $10(27.0)$ \\
\hline Colonoscopy + Open surgery & $3(8.1)$ \\
\hline Laparoscopic surgery & $2(5.4)$ \\
\hline Laparoscopic surgery + Open surgery & $1(2.7)$ \\
\hline Open surgery + Colonoscopy + Open surgery & $1(2.7)$ \\
\hline \multicolumn{2}{|c|}{ aAccompanying malformations: 2 intestinal malrotations, 1 hypoplastic left heart syndrome, 1 cystic fibrosis } \\
\hline \multicolumn{2}{|c|}{ bSixteen patients $(16 / 37,43.2 \%)$ had the three symptoms: abdominal pain, bloody stool, and vomiting } \\
\hline \multicolumn{2}{|c|}{$\begin{array}{l}\text { 'Misdiagnosis: } 4 \text { mesentery lymphadenitis, } 4 \text { infectious gastroenteritis, } 2 \text { fecal impaction, } 1 \text { Meckel's diverticulum, } 1 \text { Entamobea } \\
\text { histolytica cysts, } 1 \text { enterospasm, } 1 \text { unknown }\end{array}$} \\
\hline $\begin{array}{l}\text { d The above-summarized results were all mentic } \\
\text { included study were considered to be absent }\end{array}$ & t were not mentioned in the \\
\hline
\end{tabular}

Details of the treatment administered to each patient are shown in Fig. 2. Therapeutic enema was performed in 21 patients (21/37, $56.8 \%)$ and successfully reduced intussusception in 12 patients (12/21, 57.1\%). Twelve patients (12/37, 32.4\%) underwent open surgery directly. Thirteen patients $(13 / 37,32.4 \%)$ underwent colonoscopy, among whom 3 switched to open surgery- 1 with a sessile juvenile polyp, 1 with multilobulated broad-based lipoblastoma, 1 with obstructive synovial sarcoma.

\section{Discussion}


Colocolic intussusceptions in children are far less common than ileocolic intussusceptions, occurring in less than $5 \%$ of most case series except on the African continent, and most have a pre-existing colonic pathology acting as a lead point $[5,6,25,26]$. The incidence of colocolic intussusception was $0.8 \%$ at our center, a value lower than that reported in the literature. The reason might be related to ethnic and geographic differences. Additionally, patients with intussusception treated successfully by air enema at the outpatient department were not included in our case series, which affected the incidence. A review of the studies published in the past 20 years showed that unlike the male predominance reported in previous studies on all types of intussusception, no such predominance was identified among patients with colocolic intussusception, as reported in previous surveys [26]. Our study also confirmed that the age at the development of colocolic intussusception was older on average than that of patients with ileocolic intussusception $[27,28]$. The reason might be associated with pathologic lead points, such as juvenile polyps, which occur most commonly in children older than 2 years of age [29].

The clinical symptoms of abdominal pain, bloody stool and vomiting are often considered the main features of intussusception. However, less than $25 \%$ of patients have this classic triad, leading to a delayed diagnosis or misdiagnosis [30]. Among patients with colocolic intussusception in our study, the proportion with the above classic triad was as high as $43.2 \%$, but $37.8 \%$ were still misdiagnosed. The reason was mainly related to the less severe symptoms of the patients at the initial visit, lack of imaging examination or successive occurrence of the above symptoms [5,6]. Our study also confirmed that, unlike patients with ileocolic intussusception who almost always had abdominal masses, a significantly lower proportion of patients with colonic intussusception had abdominal masses, most of which were located in the left abdomen; instead, patients with colonic intussusception had a significantly higher incidence of rectal masses or prolapse. Both ultrasound and computed tomography are useful tools to diagnose intussusception [31]. Ultrasound is recommended first and should be used at the initial visit for all children with the above symptoms and a clinical suspicion of intussusception, including colocolic intussusception [32].

Given the pathologic lead points found in most colocolic intussusceptions, therapeutic enemas, especially hydrostatic barium enemas, were previously considered to be avoided, and these patients often required open surgery [33]. However, treating colocolic intussusception caused by a pathologic lead point is currently considered the same as treating those without a pathologic lead point, involving a careful attempt at reduction using a minimally invasive approach [7]. Similar to the findings in the recent systematic review of intussusception, our study suggested that for colocolic intussusception, without peritonitis (e.g., diffuse abdominal tenderness), a therapeutic enema could be performed first [34]. The success rates of a therapeutic enema to the treat colon intussusception with and without pathologic lead points in our study were $52.9 \%(9 / 17)$ and $75.0 \%(3 / 4)$, respectively. A colonoscopy can be performed to investigate the colon wall and identify the pathologic lead point in patients with successful therapeutic enemas and performing a colonoscopy can sometimes help reduce intussusception in patients in whom the therapeutic enema has been unsuccessful $[6,7]$.

As described in most studies in the literature, active intervention is required for colocolic intussusception caused by pathologic lead points because the presence of lead points may impair complete reduction of intussusception and the recurrence rate is still high even after a successful therapeutic enema [6, 10,33]. According to our study, juvenile polyps are the most common lead point in patients with colocolic intussusception, and using a therapeutic enema followed by colonoscopic polypectomy was found to be a feasible intervention to treat these patients. Among the 7 patients with successful therapeutic enemas who underwent colonoscopy subsequently, $6(6 / 7,85.7 \%)$ had their polyps successfully removed, and 1 with a sessile polyp found during colonoscopy underwent segmental colonic resection. Additionally, to our best knowledge, the current study reported the largest variety of pathologic lead points of colocolic intussusception other than juvenile polyps and found that all patients with colocolic intussusception caused by other pathologic lead points had received surgical interventions (12 open surgeries, 2 laparoscopic surgeries and 2 colonoscopic polypectomies), except for 1 with colocolic intussusception caused by hereditary angioneurotic edema. The main reasons for the increased use of open surgery may be as follows. First, most pathologic lead points were rare, and clinicians lacked the awareness and treatment experience of these intussusception types. Second, even if the intussusception was successfully reduced by therapeutic enema, some pathologic lead points, such as synovial sarcoma and lipoblastoma, could not be removed by colonoscopy. Third, after successful reduction by therapeutic enema, some pathologic lead points located outside the colon could not be observed by colonoscopy, such as the ileal invagination of the sigmoid colon [12, 23, 24]. Additionally, Abrahams et al. reported 1 patient with colocolic intussusception caused by a juvenile polyp who had undergone laparoscopic exploration after a successful therapeutic enema, but no abnormality was found; the patient had undergone open surgery subsequently because of the recurrence of symptoms [10]. Thus, open surgery remains the primary treatment in patients with colocolic intussusception and may be preferable to 
laparoscopic surgery. However, the identification rate of pathological lead points by open surgery also did not reach $100.0 \%$. For example, the case of colocolic intussusception caused by capillary hemangioma reported by Utsumi et al. could only be accurately resolved by open surgery with colonoscopic assistance [17]. Further studies with larger samples are needed to confirm this finding.

With advances in ultrasound and computed tomography, an increasing number of patients can be diagnosed with or without pathologic lead points [17, 33]. If the colocolic intussusception caused by pathologic lead points was reduced by therapeutic enema, we recommended that patients be hospitalized for a period of time to relieve bowel edema and receiving adequate bowel preparation before deciding the best way to manage the pathologic lead points, an approach that could be helpful for reasonable surgical selection and improve the overall prognosis [7]. However, except for juvenile polyps, identifying the specific type of lead points preoperatively remains challenging. No study has reported the differences in imaging findings between different pathologic lead points, which would be helpful to develop a standard diagnosis and treatment procedure for colocolic intussusception in the future.

The study has several limitations. First, all the included studies were retrospective, and the patient population was small. Second, some studies had not fully reported the results, which may have confounded the findings. Finally, literature reviews did not include all published studies (before 2000), leading to potential bias. A multicenter prospective study of colocolic intussusception is recommended in the future.

\section{Conclusion}

A therapeutic enema followed by colonoscopic polypectomy is feasible as a treatment for colocolic intussusception caused by juvenile polyps unless the patient has signs of peritonitis due to bowel perforation; However, open surgery is sometimes needed. For patients with colocolic intussusception caused by other pathologic lead points, colonoscopy can be used as a diagnostic method, and open surgery remains the primary treatment. The role of laparoscopic surgery in colocolic intussusception is debatable.

\section{Declarations}

\section{Ethics approval and consent to participate}

This study adheres to the ethical principles of the Declaration of Helsinki. It was approved by the Ethics Committee of Beijing Children's Hospital ([2021]-E-090-R). For the presented retrospective data, the requirement to obtain informed consent was waived in accordance with the vote of the Ethics Committee of Beijing Children's Hospital.

\section{Consent for publication}

Not applicable.

\section{Availability of data and materials}

All data generated or analyzed during this study are included in this published article.

\section{Competing interests}

The authors declare that they have no competing interests.

\section{Funding}

No source of funding for the study.

\section{Authors' contributions}

All authors read and confirmed the final manuscript. JYY contributed to data collections, data analysis, drafting the manuscript and writing the paper; QLS contributed to drafting the manuscript and writing the paper; CHP and WBP contributed to data analysis and drafting the manuscript; YJC contributed to study design, data analysis and writing the paper.

\section{Acknowledgments}


We would like to thank Yueping Zeng for assistance in retrieving the hospital/medial record numbers for the electronic patient records needed for data collection. YJY thank his parents for always accompanying him to grow up.

\section{References}

1. Wang A, Prieto JM, Ward E, et al. Operative treatment for intussusception: should an incidental appendectomy be performed?. J Pediatr Surg. 2018;54(3):495-9.

2. Kaiser AD, Applegate KE, Ladd AP. Current success in the treatment of intussusception in children. Surgery. 2007;142(4):469-77.

3. Cho MJ, Nam CW, Choi SH, et al. Management of recurrent ileocolic intussusception. J Pediatr Surg. 2020;55(10):2150-3.

4. Emil S, Shaw X, Laberge JM. Post-operative colocolic intussusception. Pediatr Surg Int. 2003;19(3):220-2.

5. Soccorso G, Puls F, Richards C, et al. A ganglioneuroma of the sigmoid colon presenting as leading point of intussusception in a child: a case report. J Pediatr Surg. 2009;44(1):e17-20.

6. Richer EJ, Dickson PN. Colocolic intussusceptions in children: a pictorial essay and review of the literature. Emerg Radiol. 2020;27(1):97-102.

7. Takahashi T, Miyano G, Kayano H, et al. A child with colo-colonic intussusception due to a large colonic polyp: case report and literature review. Afr J Paediatr Surg. 2014;11(3):261-3.

8. Rais R, González I, Saito JM, et al. Infantile hemangioma presenting as colocolic intussusception in an infant case report with review of pathologic lead points. Case Rep Pediatr. 2018;24:6494075.

9. Adorisio O, De Peppo F, Rivosecchi M, et al. Enterobius vermicularis as a cause of intestinal occlusion: how to avoid unnecessary surgery. Pediatr Emerg Care. 2016;32(4):235-6.

10. Abrahams RB, Franco A, Lewis KN. Pediatric colocolic intussusception with pathologic lead point: a case report. Journal of medical cases. 2012;3(1):84-8.

11. Pritzker HA, Levin TL, Weinberg G. Recurrent colocolic intussusception in a child with hereditary angioneurotic edema: reduction by air enema. J Pediatr Surg. 2004;39(7):1144-6.

12. Abantanga FA. Ileal invagination of the sigmoid colon producing a sigmoidorectal intussusception combined with rectal prolapse in a 3-year-old child. Pediatr Surg Int. 2005;21(5):400-2.

13. Hafen GM, Taylor AC, Oliver MR, et al. Intussusceptions arising from two different sites in a child with cystic fibrosis. Pediatr Pulmonol. 2005;40(4):358-61.

14. Tennant S, Halliday K. Intussusception mimicking rectal prolapse. Pediatr Radiol. 2008;38(6):700-2.

15. Rahim M, Shahsanam G, Vahed SN. Colocolic intussusception without lead point; a case report and literature review. Iran J Pediatr. 2008;18(4):373-6.

16. Al-Jahdali A, Lees GM, Gay DP, et al. Colocolic intussusception in a preterm infant with intestinal malrotation. J Pediatr Surg. 2009;44(12):e17-8.

17. Utsumi K, Ogasawara N, Sasaki M, et al. Intussusception in a child caused by capillary hemangioma of the colon. Clin J Gastroenterol. 2010;3(2):83-7.

18. Sanchez S, Javid P, Ricca R, et al. Colocolonic intussusception in a four-yr-old with a heart transplant: a case report and review of the literature. Pediatr Transplant. 2012;16(6):e225-8.

19. Das A, Ralte L, Chawla AS, et al. Colocolic intussusception in an older child: a rare case report and a literature review. Case Rep Surg. 2013;2013:106831.

20. Ratan SK, Goel G, Sobti P, et al. Colonic gastrointestinal stromal tumour presenting as intussusception. APSP J Case Rep. 2013;4(2):19.

21. Kurian JJ, Kishore R, John TJ, et al. A rare case of kaposiform hemangioendothelioma presenting as intussusception in a 4month-old child without Kasabach-Merrit syndrome: a case report. J Indian Assoc Pediatr Surg. 2014;19(4):233-5.

22. Tripathy PK, Jena PK. Colocolic intussusception in a child with pathologic lead point along with intestinal malrotation-a rare case report and brief review. J Clin Diagn Res. 2016;10(12):PD9-10.

23. Eid Y, Dupont-Lucas C, Orbach D, et al. Synovial sarcoma presenting as colonic intussusception in a child. Pediatr Blood Cancer. 2017;64(1):207-8. 
24. Brundler MA, Kurek KC, Patel K, et al. Submucosal colonic lipoblastoma presenting with colo-colonic intussusception in an infant. Pediatr Dev Pathol. 2018;21(4):401-5.

25. Arthur AL, Garvey R, Vaness DG. Colocolic intussusception in a three-year-old child caused by a colonic polyp. Conn Med. 1990;54(9):492-4.

26. Davies MR, Cywes S. Colonic intussusceptions in children. S Afr Med J. 1978;54(13):517-9.

27. Otero HJ, White AM, Khwaja AB, et al. Imaging intussusception in children's hospitals in the United States: trends, outcomes, and costs. J Am Coll Radiol. 2019;16(12):1636-44.

28. Yap Shiyi E, Ganapathy S. Intussusception in children presenting to the emergency department: an Asian perspective. Pediatr Emerg Care. 2017;33(6):409-13.

29. Ibrahimi N, Septer SS, Lee BR, et al. Polyp Characteristics of nonsyndromic and potentially syndromic juvenile polyps: a retrospective cohort analysis. J Pediatr Gastroenterol Nutr. 2019;69(6):668-72.

30. Applegate KE. Intussusception in children: evidence-based diagnosis and treatment. Pediatr Radiol. 2009;39(2):140-3.

31. Ratcliffe JF, Fong S, Cheong I, et al. Plain film diagnosis of intussusception: prevalence of the target sign. AJR Am J Roentgenol. 1992;158(3):619-21.

32. Ayaz UY, Dilli A, Ayaz S, et al. Ultrasonographic findings of intussusception in pediatric cases. Med Ultrason. 2011;13(4):272-6.

33. Ein SH. Leading points in childhood intussusception. J Pediatr Surg. 1976;11(2):209-11.

34. Kelley-Quon LI, Arthur LG, Williams RF, et al. Management of intussusception in children: A systematic review. J Pediatr Surg. 2021;56(3):587-96.

\section{Figures}

PRISMA 2020 flow diagram for new systematic reviews which included searches of databases, registers and other sources

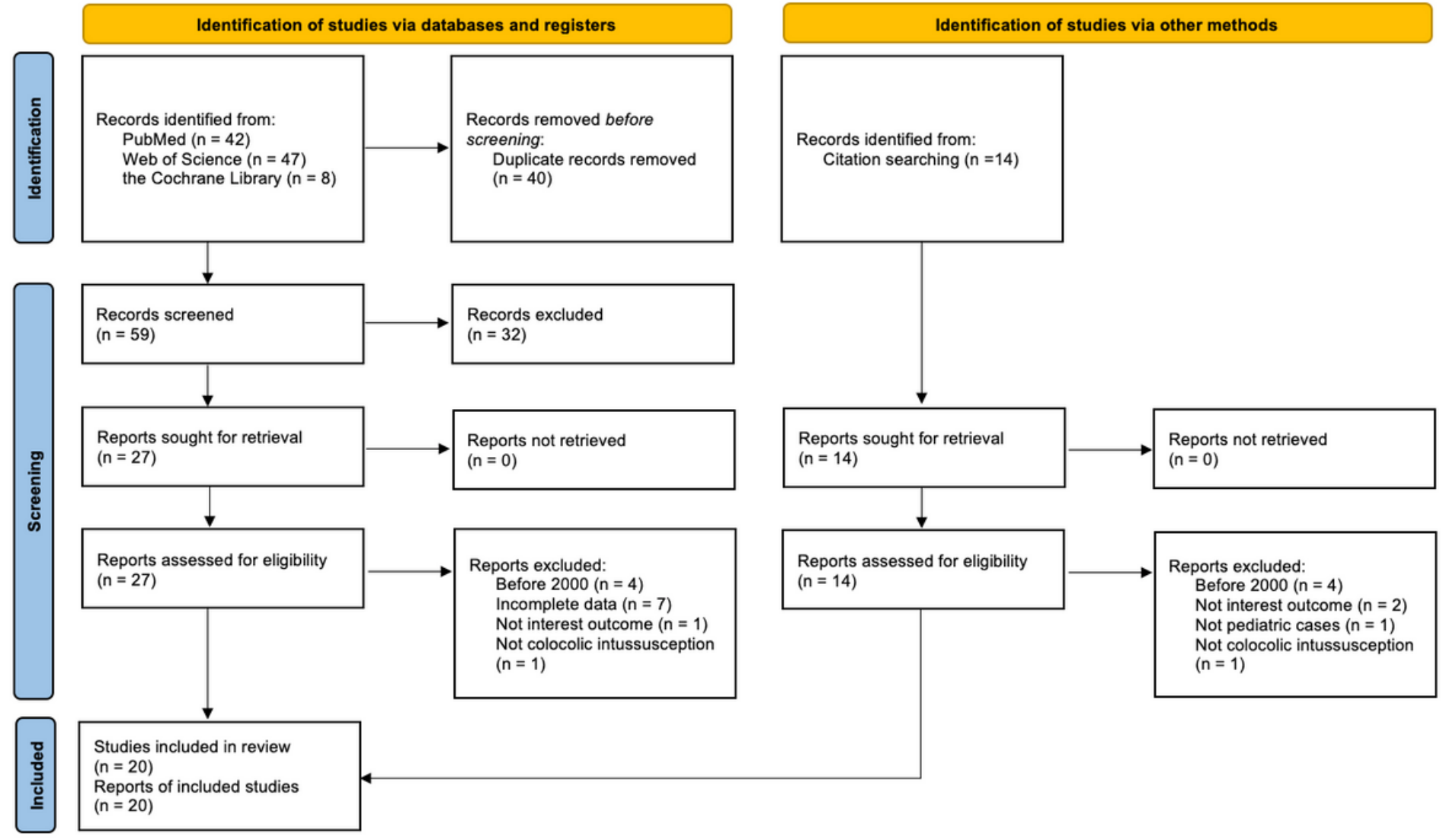

\section{Figure 1}

PRISMA flowchart for study selection 


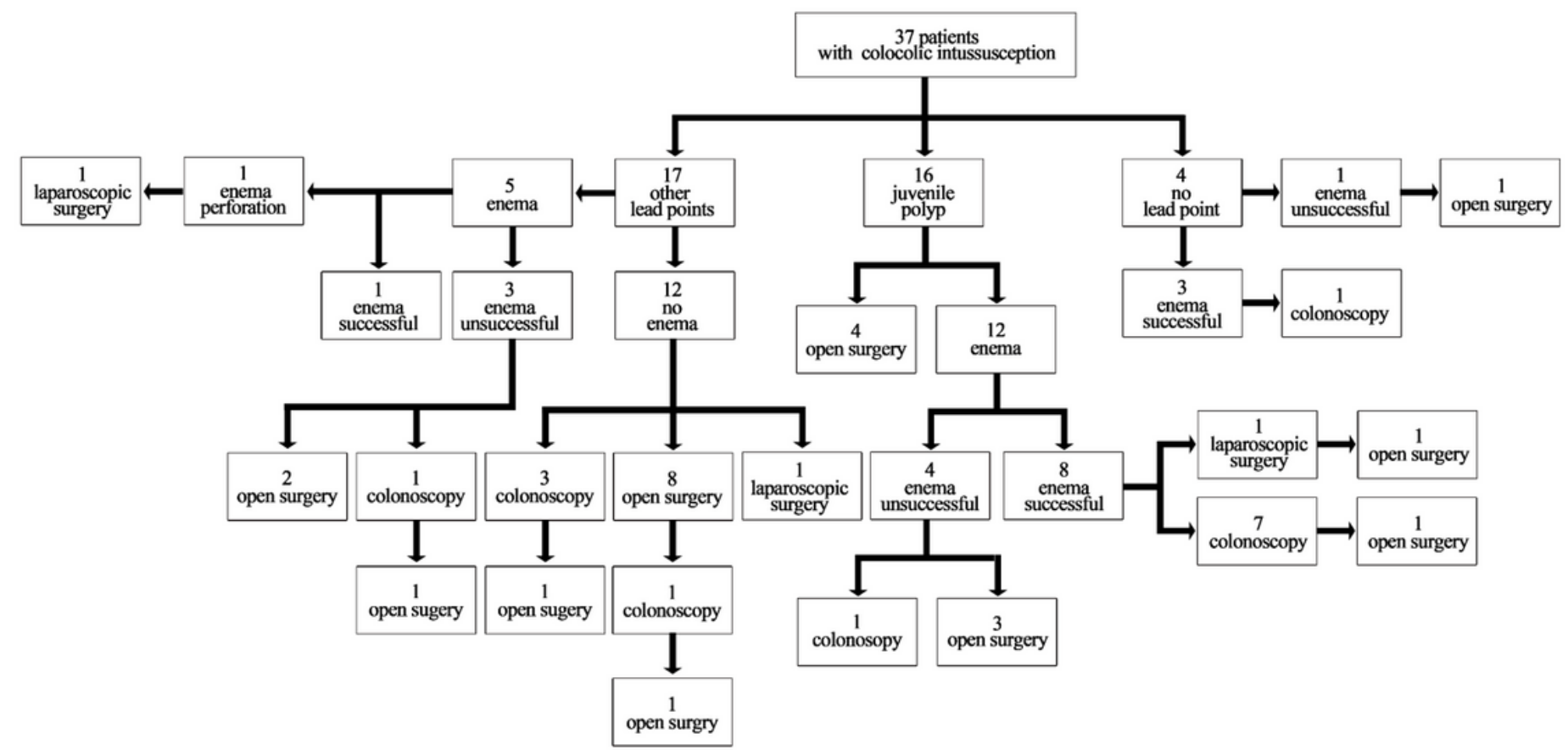

Figure 2

Details of the treatment for patients with colocolic intussusception $(N=37)$ 